\title{
MONTWG ACTIVITIES
}

FIRST DIVISION - Devamin Company, Ine. Is the name of the conpany that will be leve ing the Yakobl Island aickel deposits this year. A helicopter is already on the wo to the acene of operations, and several drilling crews are planned.

SECOND DIVISION - We pulled a real boner last month In reporting the purchase of th: gavenstrite placer operations near Candlo. Jack Bullock of Kotzebue was the purcha er, not the Ringatad family. our apologies.

THIRD DIVISION - The Maclaren River copper property is going ahead with development work under the direction of $\mathrm{Mr}$. Herve Ashby, a mining engineer of long experlence.

\section{OI NEWS}

The Humble oll Co. well in the Bear Creek Unit on the Alabka Peningula is now below 10,656 leet. Humble recently announced that their exploration activities would be sonewhat curtalled this year because of increasing costs.

The Standard and Richfield well at the Deep Creek UnIt on the Ken has passed the 8,418 -foot mark.

1n 1958.

Colorado oll \& Gas Corp. plans a third well in the Yakutat area for later

The Department of the Interior announced the opening of the PLO 82 lands of the Arctic slope for oll leasing except for the 2-rile so-called "buffer zone" around the Pet 4 area and the 5 milision acres eat of the Canning RIver which wll be part of the 9,000,000 acre Arctic W11dlife Renge w1thdrawal, if the withdrawal 1s enacted. Sixteen thousand scres of the released area are within the Gubic Gas Fleld structure and $w 113$ be offered to competitlve bldding only. The remalader of the land w131 be open to non-competitive leasing about Jume 1, 1958 and also to mineral entry under the mining laws after september 1, 1958.

One well-inforined individual sumed up the Alasken ofl leasing situation somewhat as follows (with two of our own figures substitutued for bis): of the $375,000,000$ acres in Alaske, $110,000,000$ have been classifled as belng geological1y posible or fevorabe for petroleun development. of th1s $110,000,000$ acres, about $24,000,000$ are in Petroleum Reserve No. 4 and 2,000,000 are in the Kenat Moose Rang leaving a balance of some 84,000,000 acres for leasing and development. About $30,000,000$ acres have already been leased or covered by offers to lease. Inis leav $a$ belance of about 54,000,000 scres open. At the present filing rate, 1t appears $t$. this balance w1ll be at least helf gone in another 12 montba and probably all gone by 1960 . A few more dibcovery wells will, of courge, increase the 11ling rate. Fo those who want to get in on the show, it appears that the time is short. 


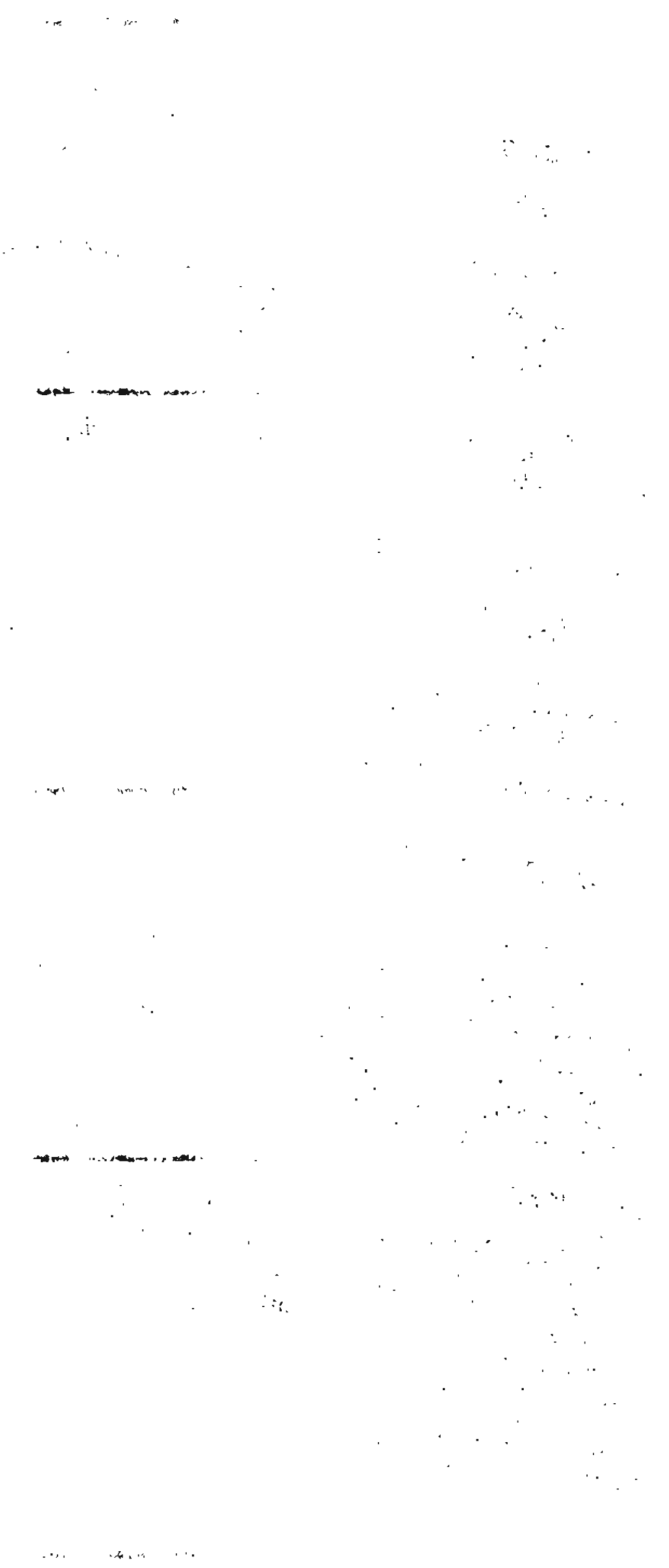


MORE ON THE PROPOSED ARCTIC WIIDLIFE WIIHDRAWAL

As mentioned in our last bullet1n, because no public hearing announcement seemed to be forthcoming, we sugge日ted thet the proposed Arct1c Wildilfe Rango be set up with a proviaion for mining aimilar to that of Glacler Bay National Monument. This provision 18 to allow patents to mineral claims to convey title to mineral rigl only, and not surface rights. In some quarters the above suggestion was takea to mean that we are now endorsing the withdrawal. We most certainly are not. It was merely a suggestion thet if this witharawal is inevitable, then give inining that mac of a break ratber than the proposed leasing system. Actually, our suggestion bas not found favor in the mining Industry, who say that it would be another step towaro hardrock leasing on public domeln landa.

In view of the continued efforts to create a National Wilderness Preserva. tion system (within which Industrial develogment is discouraged or prohtbited and which would Include some 13 mljlion acres of existing withdrawels in Aleska) we cannot oupport any effort to increase the area which would be managed under the restricted land-use-plan of a Wilderness System.

\section{P. I. 167 AREAS FOR DEITERMIATION OF SURFACE RIC\#MS}

Three more areas have been designeted by the U.S. Forest Bervlce for the determination of sumface rights on mining clatms under Fublic Law 167 of July 23,19 These are in addition to many earlier areas within the Tongags and Chugach National Forests, all reported in earlier 1saues of the TDM Bulletin. Bolders of claims stal prior to the date of the Act have 150 days from the atarting date of publication to flie verifled otatements if they wigh to retaln exclusive surface rights to their cleims. Descriptions of the new areas follow:

Eegle River Area: In general, all the mainland rest of the glaciers from Echo Cove In Berners Bay south to Lemon Creek, which is fust north of Juneau.

Tater Inlet Area: In general, all Iand bounded on the south by an eastwest IIno through Pt. Blshop, on the east by a north-8outh line through Cooper Pt. and the Annex Creek power house, on the north by the south shores of Annex Lakes and the glecters, and on the wegt by a line through the head of Granlte Creek and Sellsbury Polnt.

Northwest Chichagof Igland Area: In generel, all of Yakobl Islend and thi part of Chlcherof Irlend bounded on the north and north east by a line Ir Rock Pt. to the head of the pess Beparating Llslangky Inlet and Hoonah Sound, on the east by a line from the pass to Hirst Mt., and on the south by an east-west line from Elrst Mtn. to Portlock Harbor, and lncluding adjacent maller 1slands.

\section{INEW AEROMAGNETIC MAPS}

The U.S.G.S. has released some new aeromagnetic maps. One 1s entitled Ceophysicel Invest1gations GP Map 156, "Aeromagnet1c mep of the Copper RIver Bas1n, Alaska" by G. E. Apdreasen and others. It 18 a total intensity map made as a regult of a survey in 1954 and 1955 . It covers the area from $61^{\circ} 45^{\circ}$ to $63^{\circ} 00^{\prime} \mathbb{N}$ Ist1tude 


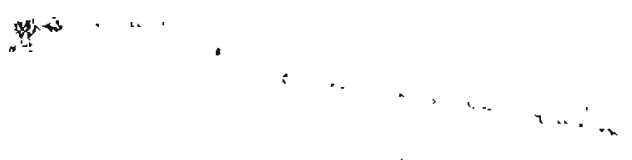

. $\sin -1$

1. מ

areแ:

$\therefore: \div$

- . . .

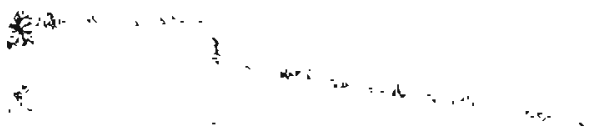

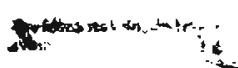

,
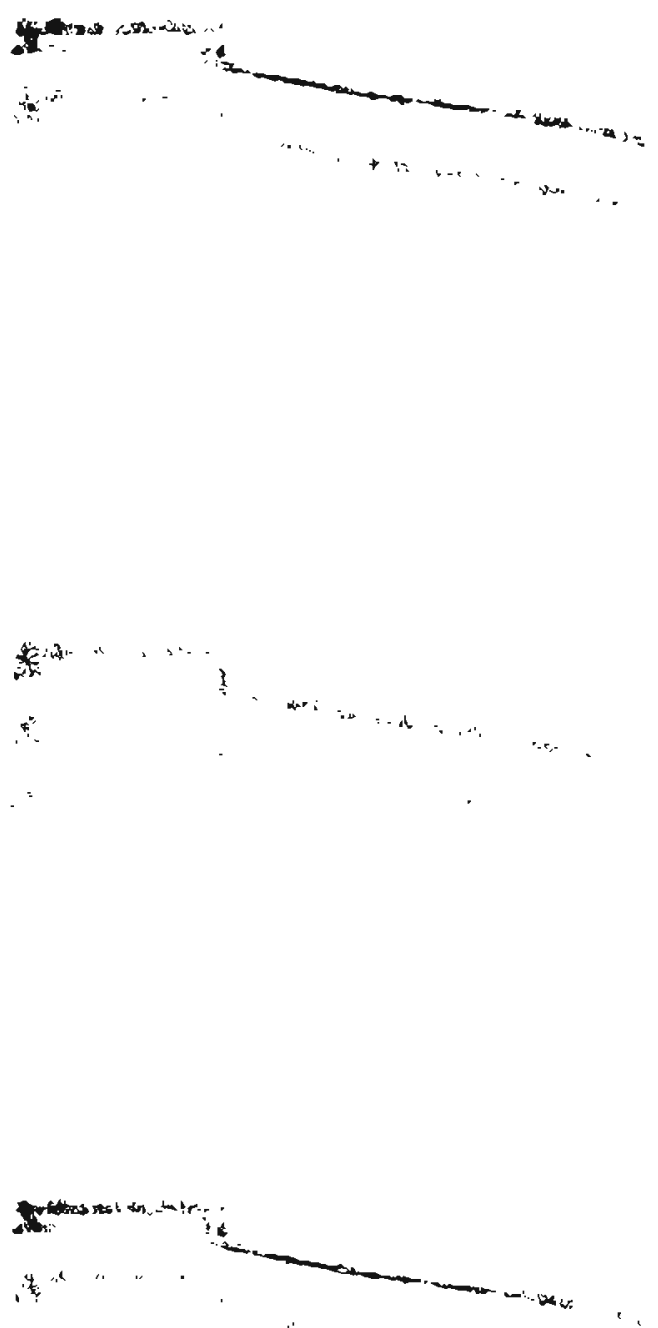

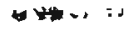

s. - I.t.

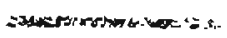

2

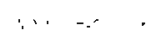

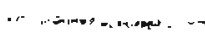

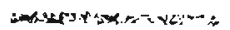

点

$+\cdots$ 
and from $145^{\circ} \mathrm{O0}$ to $147^{\circ} 20^{\prime} \mathrm{W}$ longltude. The map may be seen at the Juneau, Anchora, and College TDM offices, may be ordered for $75 \%$ from the U.S.G.S. at the Denver Federal Center, Denver 2, Colorado, or may be purchased over the counter from the U.S.G.S. In the Glover Building, Anchorage.

Three others are aexomagnotic maps of parts of the Ugashtk and Karluk quadrangles (Kodiak area), of part of the Dillingham quadrangle, and of part of the Naknel quadrangle. These tbree maps are only in open f1le report form, but reprodu tIOns at private expense are avaliable at the GS at 4 Homewood Place, Menlo Park, Callfornia. They may be seen at the Juneen TDM offlce and at the Alaske U.S.G.S. offlces.

E. AND M. J. METAL MARKET PRICES

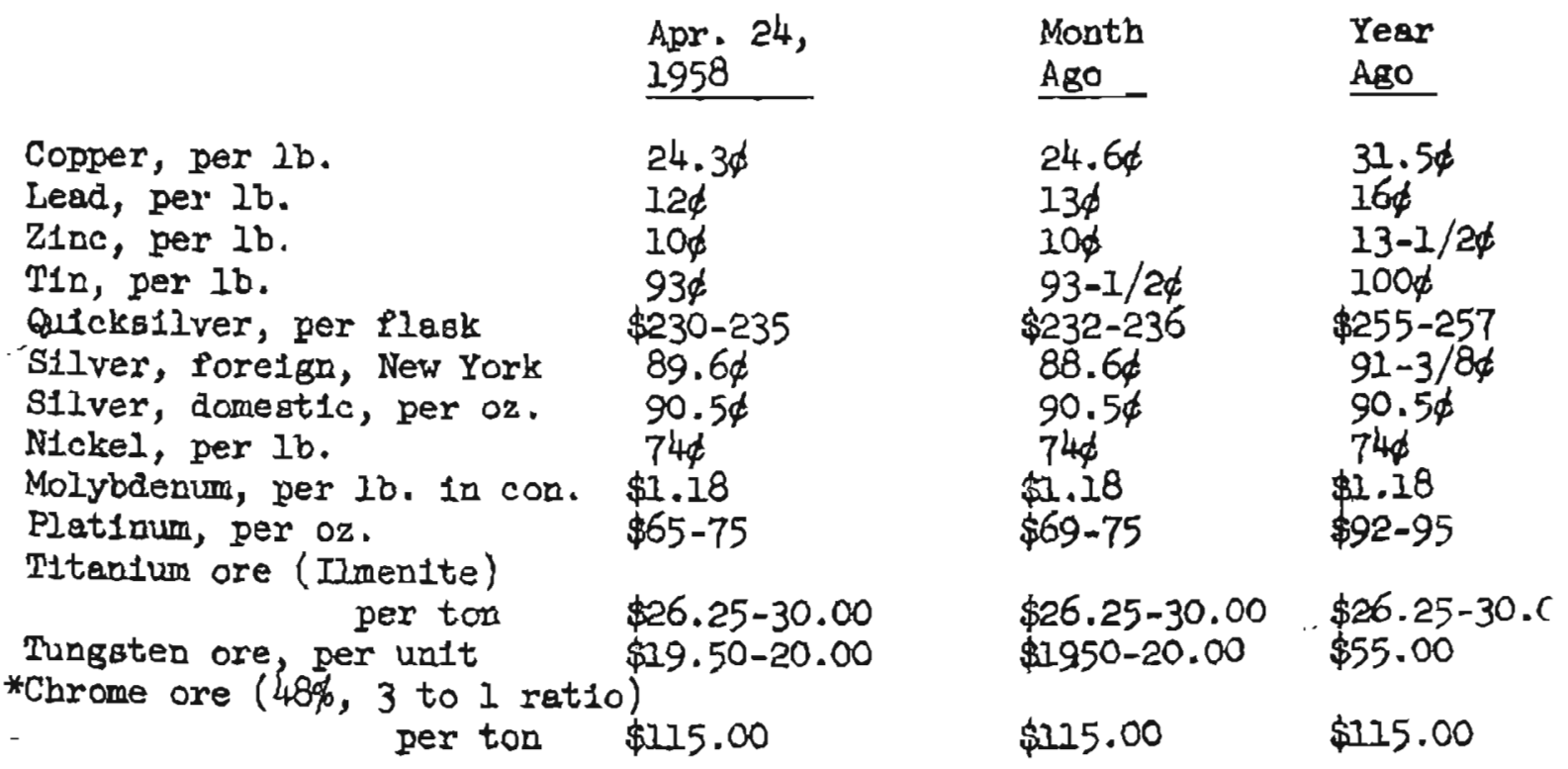

*GSA guaranteed stocikplle price. Not quoted my E. \& M. J. 


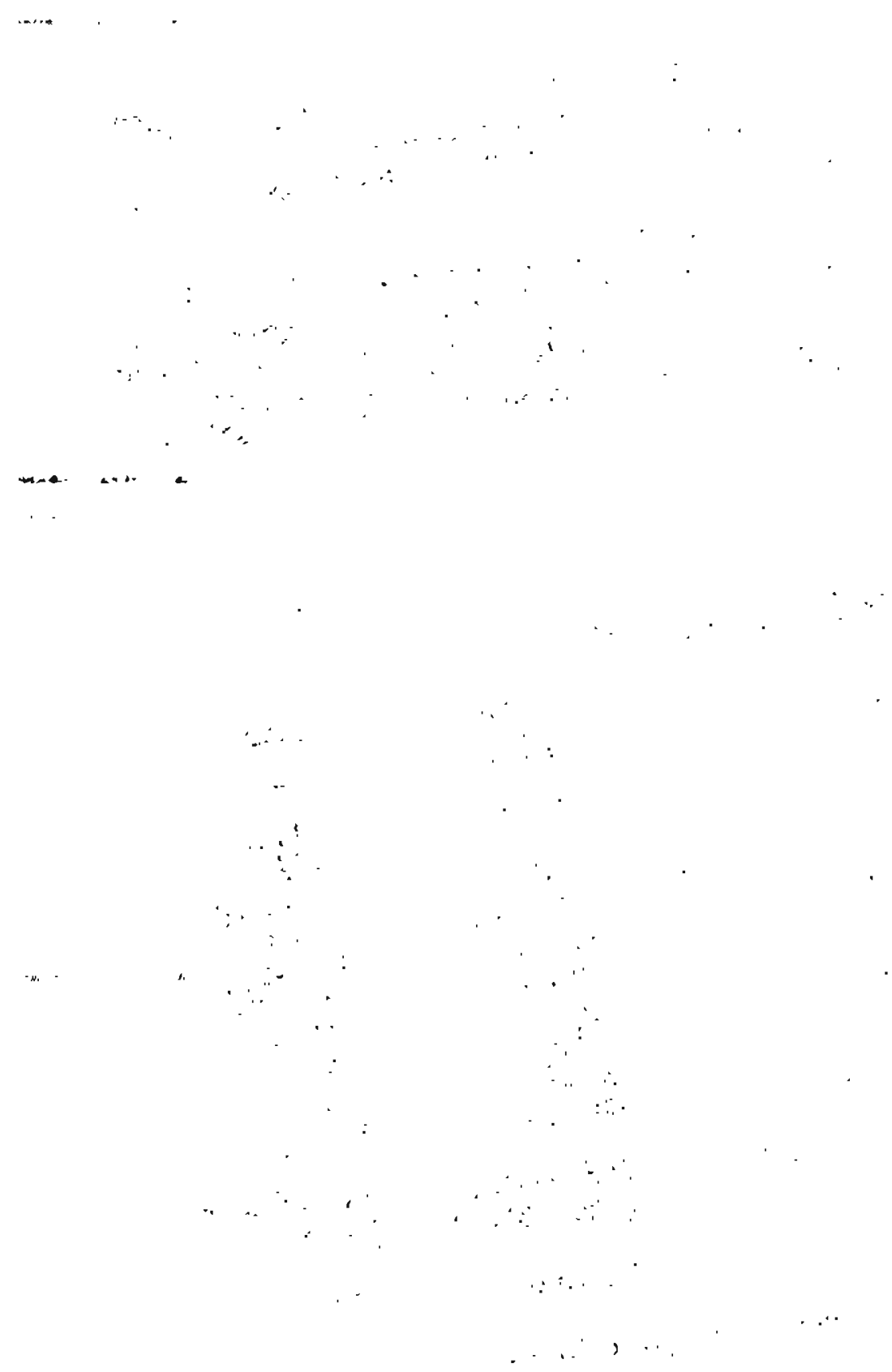

$\rightarrow \quad \ldots \quad$ a. 
MTUERAL PROIUCTION TH ALASKA, 1956-57 I/

\begin{tabular}{|c|c|c|c|c|}
\hline \multirow[b]{2}{*}{ Mineral } & \multicolumn{2}{|c|}{1956} & \multicolumn{2}{|c|}{1957} \\
\hline & $\begin{array}{l}\text { Bhort tons } \\
\text { (unless } \\
\text { otherwise } \\
\text { stated) }\end{array}$ & Value & $\begin{array}{l}\text { Short tons } \\
\text { (unless } \\
\text { otherwise } \\
\text { stated) }\end{array}$ & Value \\
\hline 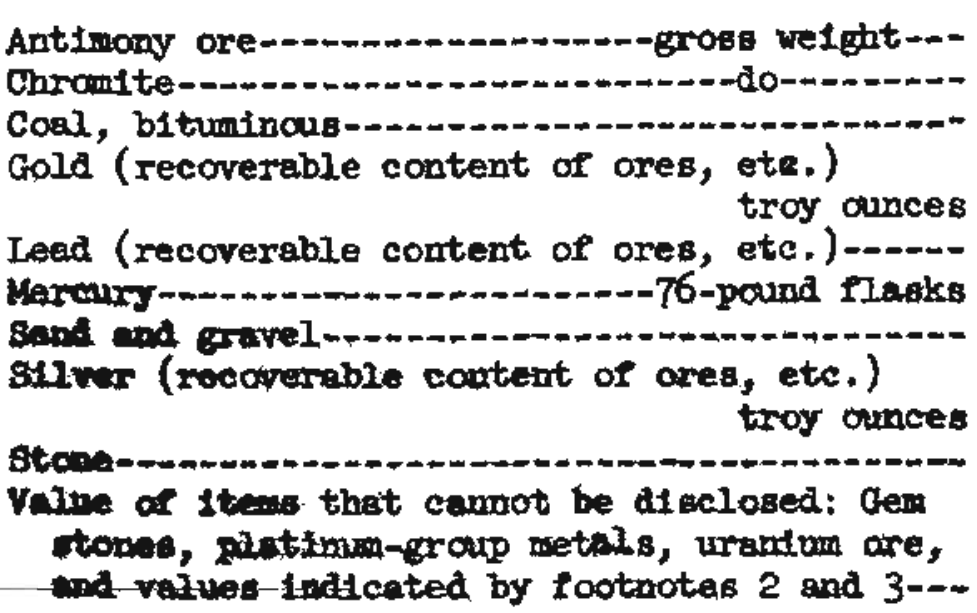 & $\begin{array}{r}(2 /) \\
7,193 \\
726,801 \\
209,296 \\
1 \\
3,280 \\
5,955,105 \\
26,360 \\
194,864\end{array}$ & $\begin{array}{r}(2 /) \\
\$ 72,481 \\
6,373,976 \\
7,325,360 \\
314 \\
852,539 \\
5,879,799 \\
25,667 \\
594,894 \\
1,643,937\end{array}$ & $\begin{array}{r}31 \\
4,200 \\
842,338 \\
215,734 \\
1 \\
5,300 \\
6,027,000 \\
26,000 \\
527,487\end{array}$ & $\begin{array}{r}\$ 5,600 \\
427,000 \\
7,292,279 \\
7,540,000 \\
268 \\
1,309,100 \\
8,708,259 \\
29,500 \\
1,946,608 \\
3,009,000\end{array}$ \\
\hline
\end{tabular}

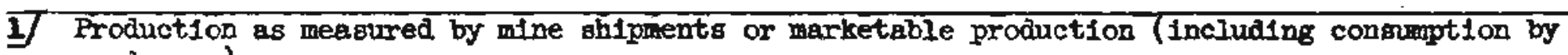
producers).

2/ Figure vithheld to avold aibclosure of Individual company confidential data.

Whe 1956 Ilgures are by the U.S.B.M. In cooperation with the TDM.

The 1957 flgures are the best estimates obtainable to date and are presented here on authority of the TOM only.

It shoild be noted that the bIg increase in the totel 1957 Plgurea is aue mostly to the nev uranium production and also to aand gravel and stone. These latter items are not truly minerals (Bince 1955) but are st111 carrled by the U.S.B.K. for statfatical reporting of neral productica throughout the U.S. 


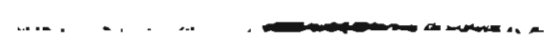

